\title{
Responding to the Hyde Amendment: Abortion Discourse, Race, and a Conspiracy of Silence
}

\author{
Momo Wilms-Crowe*, Political Science and International Studies
}

\begin{abstract}
This research project examines the discourse about abortion and reproductive justice in order to analyze how race shaped politics within the second-wave feminist movement. Specifically, I explore why more black women did not engage in the national debate about abortion in the wake of the 1976 Hyde Amendment, even when restrictive abortion legislation had a disproportionately negative effect on them. Historically, scholarship has focused either on women's liberation and feminism, or on civil rights and black liberation. This paper, however, connects those themes using an intersectional approach by examining reproductive justice in terms of women's multiple, intersecting identities, especially race, class, and gender. This multidimensional identity complicated black women's involvement in the second wave feminist movement, leading to a so-called "conspiracy of silence." Primary sources, including feminist publications, interviews, and autobiographies reveal that black women were largely absent from the mainstream pro-choice feminist discourse and mobilizations in the 1970s. Their silence and lack of involvement, however, was not because access to abortion was unimportant nor irrelevant to them. Rather, my research suggests that their silence was rooted in complex historical and ideological barriers as well as a failure of the mainstream feminist movement to consider their unique history, needs, and circumstances. This research project draws attention to the historical silences by reading "against the grain" with the aim to shed light on the complicated politics within the second-wave feminist movement and provide a framework for understanding why black women's voices were silenced in this sphere.
\end{abstract}

In the years surrounding the passage of the 1976 Hyde Amendment, which barred the use of federal funds to pay for abortion services, the independent feminist press warned about the return of the coat hangers, listed phone numbers to call adjacent to detailed scripts, and published photo upon photo of protesters. Meanwhile, black women's voices

* Momo Wilms-Crowe is a second year student in the Clark Honors College double-majoring in Political Science and International Studies and minoring in Ethnic Studies. Her primary interest lies at the intersection of identity, social change, and policy. She is curious to explore the politics of belongingness and how various radical social movements create tension by simultaneously advancing democratic ideals while exposing structural and institutional barriers to full democratic incorporation. Over her first two years at UO, she has focused specifically on issues of refugee and immigration as well as criminal justice and racial politics. She hopes to build on these interest areas over the coming years academically and beyond professionally, always connecting theory to praxis. Lending to her studies and in her mind impossible to disconnect from the classroom, Momo is a passionate student activist. She currently leads an immigrant and refugee advocacy group, No Lost Generation UO, and is involved in various other student organizations working to promote a more inclusive and accessible community. Please send correspondence to annamagd@uoregon.edu. 
were largely absent from these publications and the black press remained silent about the issue all together. Although legal abortion was an important right for women regardless of skin color, and the Hyde Amendment's attack on federally funded abortions impacted women of color disproportionately, a "conspiracy of silence" plagued black women in the 1970s. ${ }^{i}$ The divergent responses to the passage of the Hyde Amendment reflected a deeper rift in the second-wave feminist movement and suggests that restrictions on legal abortion did not have the power to unite feminists in a common cause.

The racist past of the American birth control movement, a failure on behalf of white feminists to incorporate black women, and complex ideological barriers proved too strong to successfully bridge the race divide within the feminist movement. Focusing specifically on publications in the alternative feminist press and the black press, as well as interviews and autobiographical narratives from black feminists, this paper examines why black women were largely absent in the abortion debate and mobilizations surrounding the passage of the Hyde Amendment. I outline first how the Hyde Amendment disproportionately impacted women of color, second, how black women were absent from the discourse, and third, the historical and ideological barriers that prevented black women from joining the abortion debate of the 1970s. The passage of the Hyde Amendment offers unique context for this research because it disproportionately affected women of color yet still could not diversify the movement. It is therefore an ideal event to focus on in examining racial politics within the second wave feminist movement, which raged from the 1960 s to 1980 os and focused heavily on reproductive justice. ${ }^{\text {ii }}$

While Roe $v$. Wade is often heralded as the landmark case in the legal history of abortion in the United States, the tension between abortion accessibility and restriction did not begin nor end with that infamous ruling. Abortion was first criminalized in the United States in 1867 and remained so until 1973, when the Supreme Court ruled 7-2 in Roe $v$. Wade that the decision to obtain an abortion was a woman's constitutional right under the $14^{\text {th }}$ Amendment.iii The impact of this decision on public health was undeniable; women obtained abortions at increasing rates while mortality from abortion dropped substantially due to a decrease in abortions performed illegally under unsafe and unsanitary conditions. ${ }^{\text {iv }}$ Women of color particularly benefited from the legalization of abortion. Prior to Roe v. Wade, low income women and women of color, categories that often overlapped, had the least access to skilled practitioners and were thus most at risk of nonprofessional and risky abortions, apparent in comparatively higher rates of death from abortion in the years before $1973 .^{\mathrm{v}}$ Legalization of abortion solved some of those issues. Yet, Roe $v$. Wade was not the end of the American abortion story.

Roe $v$. Wade addressed the problem of legality, but a new issue soon appeared for women seeking abortions: accessibility. On September 17, 1976, three years after women celebrated their right to legal abortion, the Hyde Amendment was added to the Department of Health, Education, and Welfare Department of Labor Appropriations 
Act. This amendment prohibited the use of federal funds to pay for Medicaid abortions outside of extreme exceptions. Suddenly, low-income women who relied on Medicaid were unable to practice their newly won civil liberty without extreme financial hardships. While written in the color-blind language of poverty, in practice the amendment undeniably impacted black women disproportionately who had a poverty rate over three times that of white women in 1977 (31.3\% and $8.9 \%$ respectively) and relied on Medicaid at the highest rates.vi Black women were also disadvantaged geographically. Zip codes with higher black populations correlated with those with few abortion clinics and were more often than not located in states where the state government adopted the Hyde Amendment as well, removing all public funding for Medicaid abortions and leaving women to cover the full cost. vii Poor women of color, the very women who benefited most from the legalization of abortion, were placed in a situation similar to what existed prior to Roe $v$. Wade as a result of this restriction.

The Hyde Amendment had clearly harmful impacts, specifically on low-income women of color. These women were now either unable to receive an abortion due to financial restrictions or had to find alternative means to pay for one. Data from before and after the Hyde Amendment shows a drop in abortion rates for non-white women beginning in 1976 while the total rate and rate for white women remains steadily increasing, suggesting that women of color were primarily impacted by the amendment.viii According to the Guttmacher Institute, one in four women who otherwise would have received an abortion carried the pregnancy to term. ${ }^{\text {ix }}$ This posed additional economic strain on women who were already struggling financially. ${ }^{\mathrm{x}}$ The majority of women, however, were desperate enough to find alternative means to obtain an abortion, evident in an increase in rates of self-induced and non-physician abortions. ${ }^{x i}$ Some women also proceeded to receive legal abortions, but often later than they otherwise would have because of the time spent finding sources of funding. This delay resulted in increased costs as well as health risks, with each week of delay increasing the risk of medical complications by $20 \%$ and risk of maternal mortality by 50\%.xii With restrictions in place, the Hyde Amendment worked against the progress made in Roe $v$. Wade by exacerbating the lack of abortion accessibility. The legislative measure created additional complications for women, disproportionately black, who already struggled financially and had benefited most from Roe $v$. Wade. Based on their especially vulnerable position, one might assume that black women would feature prominently in the pro-abortion discourse following the passage of the Hyde Amendment. My research, however, reveals that this was not the case.

A look at the national discourse about abortion at the time surrounding the passage of the Hyde Amendment reveals a paradox: while black women were most impacted by the restrictive legislation, they were largely absent in the pro-abortion feminist mobilization and open dialogue. The alternative press reveals that the second-wave feminist movement at large emphasized reproductive freedom and access to abortion. Nearly every issue during the mid to late 1970 s of New Women's Times, Women's Press, 
Big Mama Rag, and The Spokeswoman, four of the largest alternative feminist magazines of the 1970s, mentioned abortion on the front cover and contained "Abortion Updates," with detailed descriptions of current development in abortion legislation.xiii They also encouraged readers to get actively involved in the fight for abortion rights. In an article from January 15, 1978, The Spokeswoman wrote: "1978 is an election year-a third of the Senate and every seat in the House are up for re-election. Those who oppose women's right to reproductive freedom are determined to make abortion an issue in every campaign they can reach. We must be prepared to counter them."xiv Similarly, a 1977 article from New Women's Times aptly titled "Heckle Dr. Jekyll and Ride Mr. Hyde," implored readers to act, demanding, "we most protest this injustice! Write to your senators and representatives or send a public opinion message. Supports women's right to choose!" The author even provided a sample letter and the address of Henry Hyde, Republican congressman and sponsor of the Hyde Amendment.xv

These feminist magazines also reported on the many pro-choice protests that erupted in wake of the Hyde Amendment. A 1977 Big Mama Rag article described over 150 prochoice protesters who rallied at a Right to Life event where Henry Hyde was speaking. The article described women wearing coat hangers around their necks like nooses who "went into the ballroom lobby where Hyde was, linking arms chanting "Hyde kills women!"xvi Yet while photos of protesters are commonplace in these magazines, black women were rarely present. In the Big Mama Rag article photo, not one black woman can be seen, even in the shots of the huge crowd. Moreover, none of the four magazines mentioned anything about race nor the impact of the Hyde amendment on women of color specifically in their "Abortion Update" articles. The magazines mentioned that the amendment "discriminates against poor women," yet race was blatantly overlooked. The feminist press did not consider, or at least did not cover, the uniquely vulnerable position of black women in the abortion debate and did not reflect racial diversity.

One alternative feminist magazine, Off Our Backs, diverged from this trend and emphasized the intersection of race in the conversation about abortion. The November 1979 special edition issue focused on "Race and Racism" and contained multiple stories from black feminists. In one such article titled "Blaming the Victim: Feminist Racism and Feminist Classism," Hope Landrine commented on the lack of black women's involvement in the feminist movement, writing "[white] feminists might begin by asking, 'What is the structure of the women's movement that excludes these women? What is it in the nature of our theory, strategy, personality, and ideology that tells these women they need not apply, that are we not talking about them, that we are not "relevant" to them, or interested in them?"”xvii In a separate article, formatted as an open letter to her "white sisters," Barbara Smith wrote that "white feminist not only need to fight racism, but to familiarize themselves with the substance of our lives and struggle."xviii A third article offered guidelines for talking about racism within groups in an effort to start dialogue between white and black feminists like Smith called for. The authors provided discussion questions such as "how did [racism] affect you in relation 
to other people?" and "as you became a feminist, to what degree did you feel connected to women of all backgrounds and lifestyles?"xix Race was clearly an important part of the discourse. Even beyond the 1979 issue, Off Our Backs criticized the lack of a more racially united pro-choice feminist movement and gave women of color a voice that eluded the vast majority of feminist publications at this time. Yet Off Our Backs is the blatant exception.

While the feminist press and mainstream media sources reported on abortion during this period, the black press remained suspiciously silent about the matter, even as the impact was unambiguously racialized. ${ }^{\mathrm{xx}}$ Neither the National Association for the Advancement of Colored People (NAACP) nor Ebony, the largest and most popular black magazine at the time, made any statements relating to abortion following Roe $v$. Wade or the Hyde Amendment. The first mention of anything related came in April 1978 with an article about Dr. Mildred E. Jefferson, the first African American president of the Right to Life Committee and an avid pro-life advocate. ${ }^{x x i}$ An article in September of the same year about Faye Wattleton, the first African American president of Planned Parenthood Federation of America, followed.xxii These two articles, largely descriptive in nature, did not describe current events nor offer any direction for readers' action, in clear contrast to those in the feminist press that encouraged active participation and engagement. Besides this article pair, Ebony never reported once on the Hyde Amendment and the term "reproductive rights" did not appear until an article in 1990. Ebony's approach, or rather lack thereof, to abortion discourse, clearly contrasts with how the feminist press covered this content, suggesting that race guided dialogue in this context.

Ebony's letters to the editor section offered a richer narrative of the black community's relationship with abortion and revealed that many black women did indeed feel passionately about abortion and reproductive rights, despite that sentiment not being reflected in the magazine's general content. Readers submitted letters in response to the article about Dr. Jefferson and the majority of them took a pro-choice stance. For example, Shirley Thomas wrote that she was angered by Dr. Jefferson's "holier-than-thou stand against abortion" and believed that "she and her pro-life cronies should be reminded that the purpose of Medicaid is to provide medical care of the quality that the rich can afford...It allows the poor women the same options."xxiii Many of the women who wrote expressed a desire to make decisions over their own body and noted black women's uniquely vulnerable position.

The silence on behalf of the black press around abortion and the lack of diversity, in both content and authorship, in the alternative feminist press reveals what Byllye Avery, notable black feminist and health care activist, has called a "conspiracy of silence."xxiv Abortion was certainly relevant to women of color and polls reflect that black women supported abortion, so their silence hints at the existence of other restrictive factors. ${ }^{\mathrm{xxv}}$ Loretta Ross, a prominent black feminist historian and founder of the Sistersong Women of Color Reproductive Justice Collective, wrote, "it is not easy for Black women 
to talk about abortions. It is not easy for Black women to have abortions...Our abortion experiences have been invisible."xxvi This invisibility was rooted in a combination of ideological and historical barriers that limited black women's involvement. Ideological barriers were both internal, within black women's mentality, and external from the larger black community and the feminist community.

Internally, black women faced a stigma and culture of secrecy surrounding talking about women's health and abortion, suggesting the avoidance on behalf of the black press reflects similar patterns at the interpersonal level. Loretta Ross said that "it wasn't that [black women] were opposed to abortion but they weren't necessarily ready to talk about it front and center."xxvii Byllye Avery mirrored this sentiment, describing the intergenerational pattern of avoiding open discussion of sexuality and women's health in black culture. xxviii This normative barrier manifested itself in the black press' aversion to open conversation about abortion.

Another possible historical explanation for why black women were especially hesitant to join the pro-choice movement relates to its strong ties with the Sexual Revolution, a movement occurring simultaneously in the 1960s-1980s that challenged traditional codes of sexual behavior and orthodox ideas surrounding sexuality. Scholars have connected a lack of willingness among black women to openly discuss sexuality with the historical hypersexualization of black women's bodies. Black women have had to overcome many derogatory sexualized caricatures and an exploitative sexual history and thus would have had more reasons than white women to avoid open discussion of sexual freedom.xxix Aware of the many pervasive stereotypes attributed to them, black women modified their behavior, reflecting the experience of existence in what African-American scholar, W.E.B. Du Bois, called "double consciousness." Always with the looming "sense of looking at one's self through the eyes of others," black women's lives were shaped by the stereotypes perpetuated by mainstream culture. ${ }^{\mathrm{xx}}$ Their silence was, in part, an overcompensation in the effort to avoid meeting those stereotypes. Black women's interaction with sexual liberation was different than white women's for this reason.

An external barrier to black women's involvement came from the tension they felt as players positioned in between the feminist movement and the black liberation movement. As women of color, they faced unique marginalization and oppression from both the systems of racism and sexism. Neither movement fully captured their needs nor encouraged their full participation. The feminist movement was riddled with racism and elitism and some radical separatist feminists pressured women to work against men. Meanwhile, the black liberation movement was in many ways sexist, both operationally through leadership and gendered roles, and ideologically, through an emphasis on patriarchal norms. ${ }^{\text {xxxi }}$ This placed black women in a constantly tense situation, navigating between their dual identities. Gloria Joseph and Jill Lewis used the analogy of a Siamese twin to describe this dilemma, suggesting that black women were being pulled in opposite directions by distinct and incompatible interests which in turn prevents their full commitment to either movement. ${ }^{x x x i i}$ While this tension is clear, it is 
important to note that black women's dual identity is not determinative of permanent marginalization, as black feminists begin to embrace their agency and intersectional identity, using this unique positionality as a source of power.

The demographics of the second wave feminist movement at large reflected the trends in the feminist press. Both clearly lacked racial diversity and were dominated by white, middle class women. In discussing the feminist activist scene in Washington D.C. in the 1970s, Loretta Ross mentioned that, "although the city was $80 \%$ black at the time, ... we [black women] were never more than one, two, or three voices at a meeting out of twenty people." xxxiii Audre Lorde echoed this sentiment in her poem titled "Who Said It Was Simple." Lorde characterizes the complications of "interracial sisterhood" by describing a lunch meeting she had with white women where they were largely ignorant of the subtle ways in which racism pervaded society: "But I...see causes in color/ as well as sex/ and sit here wondering/ which me will survive/ all these liberations."xxxiv Finding a voice, let alone a spot, in the white-dominated feminist movement proved difficult for black women on multiple levels.

It was not only a lack of racial diversity in the feminist movement that posed problems, but also a lack of effort on behalf of white feminists to consider the unique circumstances and history of black women. Author, academic, and activist Angela Davis discussed how white abortion-rights activists of the early 1970s largely failed to consider their privilege and history, noting "had they done so, they might have understood why so many of their Black sisters adopted a posture of suspicion toward their cause."xxxv According to Davis, had white feminists done the proper research in an attempt to bring black women into the conversation, they would have understood some of the hesitations that they felt. Most white feminists in the 1970 s failed to recognize, or simply ignored, that American feminism and the birth control movement had roots in overt racism. In fact, the early American birth control movement had intimate connections with the eugenics movement in the late nineteenth and early twentieth century, which targeted women of color, deemed "unfit" by racist, pseudo-scientific standards. The history of birth control read much more like population control for non-white women, as reflected in the dark history of racist sterilization abuse. xxxvi $^{2}$

This systematic racism continued even after the Hyde Amendment, as sterilizations remained subsidized by federal funds even when abortions were not.xxxvii While we cannot assume that all black women knew these details, we can speculate that they were more aware of the racist history that directly affected their families than the middle class white feminists. Moreover, some Black nationalists, well aware of this history, painted birth control and abortions as a white supremacist plot of racial genocide, causing increased suspicion among black women who were involved with the black power movement. xxxviii In this way, the racist past of the American birth control movement provides another explanation to why women of color were hesitant to join the proabortion movement of the 1970s. Surely black women wanted to escape dangerous backalley abortions just as much as white women did, expressing pro-abortion sentiments 
was just a much more complicated action given the historical foundations of the movement.

Yet another external limiting force to black women's involvement in the pro-choice feminist movement came from the unique nature of their relationship with black men, which contradicted a "monist" approach by womens' liberation groups. Albert et al. describes monism in Liberation Theory as a political claim that "one particular domination precipitates all really important oppressions. Whether Marxist, anarchist, nationalist, or feminist, these 'ideal types' argue that important social relations can all be reduced to the economy, state, culture, or gender."xxxix The black liberation movement had recently united black Americans-men and women-in the struggle for racial justice. Thus, a profound sense of racial solidarity made joining a movement where some feminists urged separatist sentiments and openly condemned men according to monist logic difficult. Many black women found it impossible to work against the men with whom they were deeply bonded by a history of racial oppression and whom they had just recently marched alongside. The Combahee River Collective, a black feminist group, reiterated this sentiment in their statement of purpose, writing, "although we are feminists...we feel solidarity with progressive Black men and do not advocate for the fractionalization that white women who are separatists demand...We struggle together with Black men against racism, while we also struggle with Black men about sexism."xl Black women were intimately tied to their male counterparts based on their experiences of solidarity in the struggle for black liberation in a way white women could not relate to nor understand.

Feeling alienated in the mainstream feminist movement, black women increasingly looked to create alternative spaces and organizations that prioritized their unique needs and experiences. Their "double victimization" as both female and black required special attention and separate spaces in order to overcome the conspiracy of silence and counter hegemonic discourse. Loretta Ross explained the importance of these spaces for black women, saying, "white women have begun to break their silences about their abortions. But they do not speak for us. We need to start telling our own stories about how illegal abortion killed our mothers and how legal abortion saved our lives."xli These new spaces emerged as contemporary black feminist groups formed, beginning with the National Black Feminist Organization in 1973 and continuing with the establishment of the Combahee River Collective in 1974 and the National Black Women's Health Project in 1984, among others. ${ }^{x l i}$ These groups were significant in establishing official organizational capacity and visibility as well as a supporting theoretical conceptualization of what anti-racist, anti-sexist work could look like. They challenged the conspiracy of silence as dialogue about abortion opened to more diverse voices. Change, however, does not happen overnight. The birth of a more inclusive mainstream reproductive justice and feminist movement evaded the 1970s and 1980s, taking until the mid 1990 s for activists to gain a larger audience and acceptance. Although many women had been involved in the work since the early 1970s, the wider public acceptance 
and large-scale diversification of the feminist movement lagged.xliii The lack of black women's voices in the time surrounding the Hyde Amendment is but one illustration of this delay.

To be clear, these groups did not give rise spontaneously to a black feminist consciousness; black feminists, despite perhaps lacking the title, existed in practice long before these organizations formed. As the Combahee River Collective Statement of Purpose explains, "contemporary Black feminism is the outgrowth of countless generations of personal sacrifice, militancy, and work by our mothers and sisters." Prior to the creation of formal organizations, black women engaged in practices of resistance to white supremacy and patriarchy through quotidian efforts to assert agency and reclaim their bodies, a practice dating back to slavery. While this research paper focuses on openly declared expressions of pro-choice sentiment by narrowly considering press publications and protest participation, I hope to encourage further consideration of more hidden means of political resistance that black women engaged in during this time period dominated by their apparent silence. Political anthropologist James C. Scott characterizes "infrapolitics" as the small acts of barely visible resistance waged daily by subordinate groups which are "like infrared rays, beyond the visible." xliv In contrast to the "public transcript," Scott argues that a "hidden transcript" reveals that actions that may appear acquiescent or passive are in reality a strategy of active resistance. This paper fails to consider how black women engaged in infrapolitics in this time period, but urges those reading to recognize that absence of evidence is not evidence of absence and hidden narratives exist beneath the surface I've painted. Further research is necessary in this regard.

Jan Allen described women's reproductive rights in the late 1970s as "hang[ing] by a very slender thread." xlv Yet for many women, disproportionately black, the Hyde Amendment had already severed that thread. Given the cross-cutting effects of abortion, applying to all women regardless of race, restrictive abortion legislation such as the Hyde Amendment seem to provide the perfect context for women to unite in a common cause. In reality, however, the pro-abortion movement and discourse in the late $1970 \mathrm{~s}$ did not reflect racial diversity. While some feminists in the 1970 and 80 s focused on the needs of black women, the large-scale bipolar responses to the Hyde Amendment, as seen in the alternative feminist press and the black press, reflected a deep racial divide. Black women were largely absent, despite having benefited most from Roe $v$. Wade and harmed disproportionately by the Hyde Amendment's restrictions on publicly funded abortions. Although access to abortion and reproductive autonomy at large was important for black women, a conspiracy of silence limited their involvement. A complex combination of ideological and historical barriers in conjunction with racism within the feminist movement contributed to black women's silences. It should not be mistaken, however, that black women were unable to advocate for themselves during this time period. Black women did not lack agency, as seen in the activism of many 
individuals in the 1970s and the later growth of black feminist groups. Their dual identities as women and black simply made public action more difficult.

Race played a key role in the evolution of reproductive justice in America, guiding dialogue, tinting opinions, and ultimately proving that social movements are more complicated than a unifying cause. With this in mind, we move forward, with the understanding that the past is intimately tied to the present. Over 40 years later, black women are still too often marginalized. While the names Eric Garner and Michael Brown ring familiar to many Americans who know them as black men killed by police, the names Tanisha Anderson, Natasha McKenna, Yvette Smith, and countless more remain unheard and unrecognized, reflecting how black women continue to be overshadowed in mainstream mobilizations around racial justice, including the Black Lives Matter movement, founded by three black women. Meanwhile, reproductive health care continues to reflect a dramatic racial dimension. A shocking chasm exists between white maternal mortality rates and black, with black women facing a rate four to five times that of their white counterparts. xlvi Furthermore, threats to all women's reproductive rights remain as the Hyde Amendment is still in place at the federal level and in 33 states, leaving more than half of reproductive-aged women with Medicaid lacking abortion coverage. In response to these conditions, many continue to navigate the complex legal and social barriers to women's full autonomy over their own bodies. That the struggle continues reflects the urgency in understanding our movement history. I urge both scholars and citizens to acknowledge and study the silences in our history, for this act is crucial not only in our understanding of the past, but also in formulating our path into the future. 


\section{APPENDIX 1}

A.

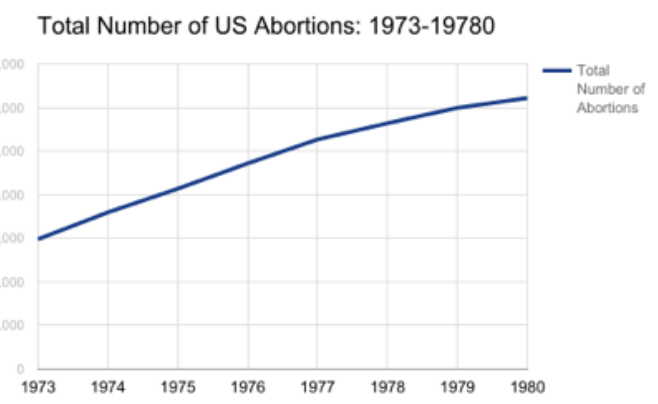

B.

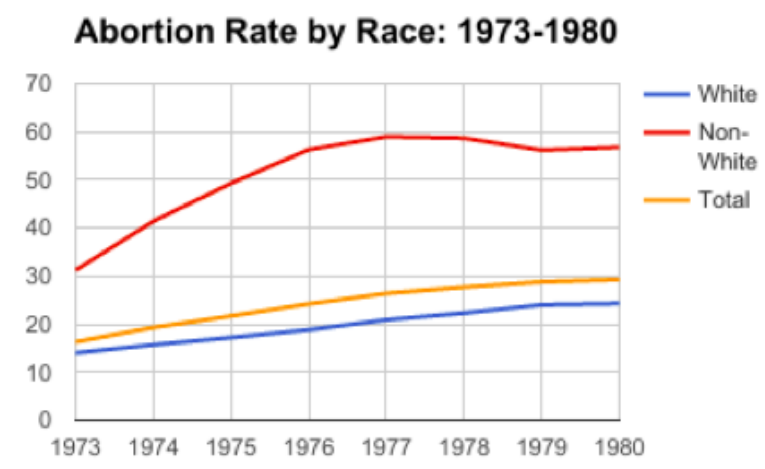

\section{ACKNOWLEDGMENTS}

Like most experiences of intense academic research, this project was a journey. Convoluted, fraught, and at times impossibly frustrating (but ultimately of course, very rewarding), this project would not have been possible without the gracious support from my professor and advisor, Tim Williams. From weekly office hours to last minute emails, Professor Williams committed himself to this endeavor, supporting this project and providing all the necessary pushes at just the right times. I cannot express enough gratitude for his guidance and support in this project. I offer additional enthusiastic thanks to Charise Cheney and Christina Faiver-Serna for their feedback in the development of this project. I must undoubtedly also thank my mother, who is easily the most influential feminist in my life and has inspired much of my academic scholarship and activism. She has pushed me to question narratives and seek deeper truths and has always been but a phone call away in times of need. Thanks always, Mom. As my first publication, this one is dedicated to you. 


\section{REFERENCES}

"80 Percent of Americans Believe Abortion Should Be Legal; 70 Percent Approve Medicaid Funding." Family Planning Perspectives 11, no. 3 (1979): 189-90. Accessed April 20, 2017.

"Aborting Abortion for Poor Women." Off Our Backs 6, no. 7 (1976): 2.

"Abortion." The Amazon 6, no. 4 ( November/December 1977): 10.

"Abortion Attacked: By Congress..." Off Our Backs 7, no. 10 (1977): 9.

"Abortion Update." Big Mama Rag 6, no. 1 (January 1978): 7.

“Abortion Update." New Women's Times 3, no. 9 (September 1977): 17.

Albert, Michael, Leslie Cagan, Noam Chomsky, Robin Hahnel, Mel King, Lydia Sargent, and Holly Sklar. Liberation Theory. Boston: South End Press, 1986.

Allen, Jan. Interview by Robin Payne. July 6, 2006. Interview U-0200. Southern Oral History

Program Collection (\#4007) in the Southern Historical Collection, Wilson Library, University of North Carolina at Chapel Hill.

Avery, Byllye. "Empowerment Through Wellness." Yale Journal of Law \& Feminism 4: no. 1 (1991).

Avery, Byllye. “A Question of Survival/A Conspiracy of Silence: Abortion and Black Women's Health." In From Abortion to Reproductive Freedom: Transforming a Movement, Edited by Marlene G. Fried, 75-81. Boston, MA: South End Press, 1990.

"Back Alley Abortions." New Women's Times 3: no. 11 (1977).

Bambara, Toni Cade. "The Pill: Genocide or Liberation" in The Black Woman: An Anthology.

New York: Washington Square Press, 2005.

Baraka, Alice. letter to the editor. Ebony. July 1977.

Barlow, Judy. "Lesbian Gay Freedom Week March.” Big Mama Rag 6, no. 7 (July 1978).

Boonstra, Heather D. "The Heart of The Matter: Public Funding of Abortion for Poor Women in the United States." Guttmacher Policy Review 10, no. 1 (2007).

Bresnehen, Eileen. "Picket greets Hyde at Rights-to-Life Dinner." Big Mama Rag 5, no. 8 (October 1977).

Caron, Simone M. Who Chooses? American Reproductive History Since 1830. Gainesville: University Press of Florida, 2008.

Cates, Willard Jr.. "The Hyde Amendment in Action." Journal of the American Medical Association no. 246 (1981): 1109.

"Congress Ends Abortion Funds in Deadlock." The Spokeswoman 8: no. 8-9 (1978).

Cross, Tia, Freida Klein, Barbara Smith, and Beverly Smith."Talking about Racism: CR Guidelines." Off Our Backs 9, no. 10 (November 1979): 9.

Davis, Angela. "The Historical Context: Racism, Birth Control and Reproductive Rights." Race, Poverty \& the Environment 4, no. 2 (1993): 21-23.

Davis, Angela Y. Women, Race, and Class. New York: Vintage Books, 1983.

Du Bois, W.E.B. The Souls of Black Folk. Chicago: Cambridge University Press, 1903.

Ebony. "A Fighter for Right to Life.” April 1978.

Emerson, Gloria. "Five Ideas That Can Change Your Life in '79." Vogue 169, no.1 (January 1, 1979): 134).

Evgenia, B. "Back to the Coathanger." Off Our Backs 6, no. 8 (1976): 9.

Feldt, Gloria. The War on Choice. New York: A Bantam Book, 2004.

Freeman, Jo. The Politics of Women's Liberation: A Case Study of an Emerging Social Movement and Its Relation to the Policy Process. New York: Longman, 1975.

Fried, Marlene Gerber, ed.. From Abortion to Reproductive Freedom: Transforming a Movement. 1st ed. Boston, MA: South End Press, 1990.

Gallup, George H. Gallup Poll: Public Opinion, 1972-1977. Wilmington, DE: Scholarly Resources (1978). 
Gilbert, Dennis. Compendium of American Public Opinion. New York: Facts On File Publications, 1988.

Gold, Edwin M., Harold Jacobziner, Frieda G. Nelson, and Carl L. Erhardt. "Therapeutic Abortions in New York City: A 20-Year Review." American Journal of Public Health and the Nation's Health 55, no. 7 (1965): 964-72.

Gordon, Linda. Woman's Body, Woman's Right: A Social History of Birth Control in America. New York: Penguin Books, 1977.

Guttmacher Institute, Abortion Factbook, 1992 Edition: Readings, Trends, and State and Local Data to 1988. New York: Alan Guttmacher Institute, 1992.

“Heckle Dr.Jekyll and Ride Mr.Hyde." New Women's Times 3, no. 11 (November 1977): 4-5. Height, Dorothy. Open Wide The Freedom Gates: A Memoir. New York: PublicAffairs, 2003. Henshaw, Stanley K., Kelly Blanchard, Theodore J. Joyce, Amanda Dennis, Lawrence B. Finer. "Restrictions on Medicaid Funding for Abortions: A Literature Review." Guttmacher Institute and Ibis Reproductive Health. July 2009.

"H.E.W. Funds Bill Stalled in House By Abortion Issue." The New York Times, August 11, 1976 Hood, Elizabeth F. "Black Women, White Women: Separate Paths to Liberation." The Black Scholar 9, no. 7 (April 1978): 45-56

Horton, Carrell P., and Jessie Carney Smith, eds. Statistical Record of Black America. Detroit: Gale Research, 1990.

Joseph, Tiffany. "Black Women in the Civil Rights Movement: 1960-1970.” Honors Senior Thesis, Brown University, 2004. Accessed online: http://cds.library.brown.edu/projects/FreedomNow/tiffany_joseph_thesis.html.

Landrine, Hope. "Blaming the Victim: Feminist Racism and Feminist Classism." Off Our Backs 9, no. 10 (November 1979): 2-3.

Lewis, Shawn D. "Family Planning's Top Advocate.” Ebony. September 1978.

Lorde, Audre. "Who Said it Was Simple." In Feminism in Our Time: The Essential Writings, World War II to the Present, edited by Miriam Schneir, 169-170. New York: Vintage Books, 1994.

Meyers, Diana T. (ed). Feminist Social Thought: A Reader. New York: Routledge, 1997.

Moore, Emily C., and Julius B. Richmond. "Woman and Health, United States 1980." Public Health Reports (1974-) (1980): 1-84.

Murray, Pauli. "Thoughts on Feminism and the Double Victimization of African American Women.” Interview by Genna Rae McNeil. February 13, 1976. Interview G-0044. Southern Oral History Program Collection (\#4007) in the Southern Historical Collection, Wilson Library, University of North Carolina at Chapel Hill.

National Black Feminist Organization. "National Black Feminist Organization Statement of Purpose." In Feminism in Our Time: The Essential Writings, World War II to the Present, Edited by Miriam Schneir, 171-174. New York: Vintage Books, 1994.

Petchesky, Rosalind P. Abortion and Woman's Choice: The State, Sexuality, and Reproductive Freedom. Revised ed. Boston: Northeastern University Press, 1990.

Reagan, Leslie J. When Abortion Was a Crime: Women, Medicine, and Law in the United States, 1867-1973. Berkeley: University of California Press, 1997.

“Remember Hyde?" Off Our Backs 9, no. 8 (1979): 6.

Roberts, Dorothy. Killing The Black Body: Race, Reproduction, and the Meaning of Liberty. New York: Pantheon Books, 1997.

Roberts, Lynn, Loretta Ross, and M. Bahati Kuumba. "The Reproductive Health and Sexual Rights of Women of Color: Still Building a Movement." NWSA Journal 17, no. 1 (2005): 93-98.

Rose, Barbara. "The Abortion Questions: Who Will Control Your Body? A Woman's View." Vogue 171, no. 9 (Sep 1 1981): 547.

Rosenzweig, Caroline, Alina Salganicoff, and Laurie Sobel. "The Hyde Amendment and 
Coverage for Abortion Services.” The Henry J. Kaiser Family Foundation. September 30, 2016.

Ross, Loretta. Interview by Cynthia Greenlee-Donnell. August 18, 2011. Interview U-1033.

Southern Oral History Program Collection (\#4007) in the Southern Historical Collection, Wilson Library, University of North Carolina at Chapel Hill.

Ross, Loretta. "Raising Our Voices." In From Abortion to Reproductive Freedom:

Transforming a Movement, edited by Marlene G. Fried, 139-143. Boston, MA: South

End Press, 1990.

Sanger, Margaret. "Why Not Birth Control Clinics in America?" Birth Control Review 3 (1919): 10-11.

Scheidler, Joseph M. letter to the editor. Ebony. May 1997.

Schneir, Miriam, ed. Feminism in Our Time:The Essential Writings, World War II to the Present. 1st ed. New York: Vintage Books, 1994.

Scott, James C. Domination and the Arts of Resistance Hidden Transcripts. New Haven, CT: Yale University Press, 2008.

Sheeley, Rita. letter to the editor. Ebony. July 1978.

Seims, Sara. "Abortion Availability in the United States." Family Planning Perspectives 12, no. 2 (1980): 88-101.

Siege, Max H. "U.S. Court Overturns Curb on Medicaid Abortions." New York Times. 23 October, 1976.

Silliman, Jael, Marlene Gerber Fried,Loretta Ross, and Elena R. Gutieİrrez. Undivided Rights: Women of Color Organize for Reproductive Justice. Chicago, Illinois: Haymarket Books, 2016.

Smith, Barbara, ed. Home Girls: A Black Feminist Anthology. 1st ed. New York: Kitchen Table Women of Color Press,1983.

"States \& Medicaid." Off Our Backs 8, no. 1 (1978): 12-12.

"Still on the Front Line: Angela Davis." Ebony. July 1990.

Smith, Barbara. "Dear Sisters..." Off Our Backs 9, no. 10 (November 1979): 13.

The Combahee River Collective. "The Combahee River Collective Statement." In Feminism in Our Time:The Essential Writings, World War II to the Present, edited by Miriam Schneir, 175-187. New York: Vintage Books, 1994.

Thomas, Shirley. letter to the editor. Ebony. July 1978.

Trussell, James, Jane Menken, Barbara L. Lindheim, and Barbara Vaughan. "The Impact of Restricting Medicaid Financing for Abortion.” Family Planning Perspectives 12, no. 3 (1980): 120-30.

Urban, Dennis J. "The Women of SNCC: Struggle, Sexism, and the Emergence of Feminist Consciousness, 1960-66.” International Social Science Review 77, no. 3/4 (2002): 185-90. http://www.jstor.org/stable/41887103.

U.S. Census Bureau, "Persons below the Poverty Level by Family Status and Race," Current Population Survey Table C, http://www.census.gov/hhes/www/hlthins/data/historical/index.html (last accessed 7 May 2017).

Villarosa, Linda. "Why America's Black Mothers and Babies are in a Life-or-Death Crisis." New York Times, 11 April 2018.

White, Deborah G. "Mining the Forgotten: Manuscript Sources for Black Women's History." The Journal of American History 74, no. 1 (1987): 237-42.

"Who Pays." Off Our Backs 7, no. (November 1977): 8.

Wood, Floris. An American Profile: Opinions and Behavior, 1972-1989: Opinion Results on 300 High-interest Issues Derived from the General Social Survey Conducted by the National Opinion Research Center. US: Gale Research Inc., 1990. 
The phrase "conspiracy of silence” was first used by Byllye Avery. See Byllye Avery, "A Question of Survival/A Conspiracy of Silence: Abortion and Black Women's Health," in From Abortion to Reproductive Freedom:

The most important works of scholarship this paper relies on include Jo Freeman, The Politics of Women's Liberation: A Case Study of an Emerging Social Movement and Its Relation to the Policy Process (New York: Longman, 1975); Rosalind P. Petchesky, Abortion and Woman's Choice: The State, Sexuality, and Reproductive Freedom (Boston: Northeastern University Press, 1990); Marlene Gerber Fried, From Abortion to Reproductive Freedom: Transforming a Movement (Boston, MA: South End Press, 1990); Dorothy Roberts, Killing The Black Body: Race, Reproduction, and the Meaning of Liberty (New York: Pantheon Books, 1997); and Jael Silliman, Marlene Gerber Fried, Loretta Ross, and Elena R. Gutieİrrez, Undivided Rights: Women of Color Organize for Reproductive Justice (Chicago, Illinois: Haymarket Books, 2016).

Leslie J. Reagan, When Abortion Was a Crime: Women, Medicine, and Law in the United States, 1867-1973 (Berkeley: University of California Press,1997): 3; Roe v. Wade, 410 U.S. 113 (1973).

Emily C. Moore and Julius B. Richmond, "Woman and Health, United States 1980," Public Health Reports (1974-) (1980): 53; Leslie J. Reagan, When Abortion Was a Crime: Women, Medicine, and Law in the United States, 18671973 (Berkeley: University of California Press, 1997): 246-7.

Edwin M. Gold et al.,"Therapeutic Abortions in New York City: A 20-Year Review," American Journal of Public Health and the Nation's Health 55, no. 7 (1965): 964-68.

U.S. Census Bureau, "Persons below the Poverty Level by Family Status and Race," Current Population Survey Table C, http://www.census.gov/hhes/www/hlthins/data/historical/index.html (last accessed 7 May 2017).

Sara Seims, “Abortion Availability in the United States," Family Planning Perspectives 12, no. 2 (1980): 88; For a study on variation of abortion accessibility across income levels, see Emily C. Moore and Julius B. Richmond, "Woman and Health, United States 1980," Public Health Reports (1974-) (1980): 72-82. For a look at poverty and geographic influences on abortion accessibility see Caroline Rosenzweig, Alina Salganicoff, and Laurie Sobel, "The Hyde Amendment and Coverage for Abortion Services," The Henry J. Kaiser Family Foundation (September 30, 2016).

See graphs A and B in Appendix 1. All data from: Guttmacher Institute, Abortion Factbook, 1992 Edition: Readings, Trends, and State and Local Data to 1988 (New York: Alan Guttmacher Institute, 1992).

Guttmacher Institute, Abortion Factbook; Trussell et al.,"The Impact of Restricting Medicaid Financing for Abortion," Family Planning Perspectives 12, no. 3 (1980): 124.

It also cost the federal government more money through welfare payments to Medicaid-eligible women who now had more children to care for. See Committee to Defend Reproductive Rights v. Myers (1981), in which the California state court declared that "whatever money saved [by not obtaining an abortion] will be spent many times over."

Willard Jr. Cates, “The Hyde Amendment in Action,” Journal of the American Medical Association no. 246 (1981): 1109; Henshaw et al. "Restrictions on Medicaid Funding for Abortions: A Literature Review," Guttmacher Institute and Ibis Reproductive Health (July 2009).

Heather D. Boonstra, "The Heart of The Matter: Public Funding of Abortion for Poor Women in the United States," Guttmacher Policy Review 10, no. 1 (2007): 23; Henshaw et al. "Restrictions on Medicaid Funding."

See “Abortion Update,” New Women's Times 3, no. 9 (September 1977): 17; “Abortion Update,” Big Mama Rag 6, no. 1 (January 1978): 7; "Back Alley Abortions,” New Women's Times 3: no. 11 (1977); “Abortion,” The Amazon 6, no. 4 ( November/December 1977): 10; "Abortion Attacked: By Congress...," Off Our Backs 7, no. 10 (1977): 9; B. Evgenia,"Back to the Coathanger,” Off Our Backs 6, no. 8 (1976): 9; "Remember Hyde?” Off Our Backs 9, no. 8 (1979): 6.

“Congress Ends Abortion Funds in Deadlock," The Spokeswoman 8: no. 8 (1978) [my emphasis].

“Heckle Dr.Jekyll and Ride Mr.Hyde.” New Women’s Times 3, no. 11 (November 1977): 4-5.

Eileen Bresnehen, "Picket greets Hyde at Rights-to-Life Dinner," Big Mama Rag 5, no. 8 (October 1977). 
Hope Landrine, "Blaming the Victim: Feminist Racism and Feminist Classism," Off Our Backs 9, no. 10 (November 1979): 3 .

Barbara Smith, “Dear Sisters...," Off Our Backs 9, no. 10 (November 1979): 13.

Cross, et al. "Talking about Racism: CR Guidelines," Off Our Backs 9, no. 10 (November 1979): 9.

See articles "H.E.W. Funds Bill Stalled in House By Abortion Issue," The New York Times (August 11, 1976) and Max H. Siege, "U.S. Court Overturns Curb on Medicaid Abortions," New York Times (23 October, 1976) for a look at how non-feminist newspapers reported on the abortion debate. Also see Barbara Rose,"The Abortion Questions: Who Will Control Your Body? A Woman's View," Vogue 171, no. 9 (Sep 1 1981): 547.

“A Fighter for Right to Life,” Ebony (April 1978).

Shawn D. Lewis, “Family Planning’s Top Advocate,” Ebony (September 1978).

Shirley Thomas, letter to the editor, Ebony (July 1978).

Loretta Ross, interview (2011); Deborah G. White, "Mining the Forgotten: Manuscript Sources for Black Women's History," The Journal of American History 74, no. 1 (1987): 238; Byllye Avery, "Empowerment Through Wellness," Yale Journal of Law \& Feminism 4: no. 1 (1991).

For a variety of statistics about public opinion over abortion, see, Guttmacher Institute,"8o Percent of Americans Believe Abortion Should Be Legal; 70 Percent Approve Medicaid Funding," Family Planning Perspectives 11, no. 3 (1979): 189-90; Carrell P. Horton and Jessie Carney Smith, eds., Statistical Record of Black America (Detroit: Gale Research, 1990); George H. Gallup, Gallup Poll: Public Opinion, 1972-1977 (Wilmington, DE: Scholarly Resources, 1978); Dennis Gilbert, Compendium of American Public Opinion (New York: Facts On File Publications, 1988); Floris Wood, An American Profile: Opinions and Behavior, 1972-1989: Opinion Results on 30o High-interest Issues Derived from the General Social Survey Conducted by the National Opinion Research Center (US: Gale Research Inc., 1990).

Loretta Ross, "Raising Our Voices," In From Abortion to Reproductive Freedom: Transforming a Movement, ed. Marlene G. Fried (Boston, MA: South End Press, 1990), 139.

Loretta Ross, interview (2011).

Byllye Avery, "Empowerment Through Wellness," 150-151.

Dorothy Roberts, Killing The Black Body: Race, Reproduction, and the Meaning of Liberty (New York: Pantheon Books, 1997): 8; National Black Feminist Organization, "National Black Feminist Organization Statement of Purpose," In Feminism in Our Time, ed. Miriam Schneir, 172.

W.E.B. Du Bois, The Souls of Black Folk (Chicago: Cambridge University Press, 1903): 351.

For details on women's marginalization and sexism within the civil rights movement, see Dorothy Height, Open Wide The Freedom Gates: A Memoir (New York: PublicAffairs, 2003); Tiffany Joseph, "Black Women in the Civil Rights Movement: 1960-1970" Honors Senior Thesis (Brown University, 2004), Accessed online; Dennis J. Urban, “The Women of SNCC: Struggle, Sexism, and the Emergence of Feminist Consciousness, 1960-66.” International Social Science Review 77, no. 3/4 (2002): 185-90.

Deborah King, "Multiple Jeopardy, Multiple Consciousness: The Context of Black Feminist Ideology,” in Feminist Social Thought: A Reader, ed. Diana T. Meyers (New York: Routledge, 1997): 236.

Loretta Ross, interview (2011).

Audre Lorde, "Who Said it Was Simple." In Feminism in Our Time, ed. Miriam Schneir, 170.

Angela Davis, “The Historical Context: Racism, Birth Control and Reproductive Rights” Race, Poverty \& the Environment 4, no. 2 (1993): 221.

Sterilization was often a condition of receiving welfare payments or abortions for poor women. This impacted women of color disproportionately. Of the 7,686 state sponsored sterilizations in North Carolina from 1933 to the early 1970 , over 5,000 of those were of African Americans. Angela Davis, “The Historical Context," 217; Moreover, these statistics were not a mistake but the result of state-sponsored racism with the goal, in the words of "the mother of American birth control," Margaret Sanger, "more children from the fit, less from the unfit." Margaret Sanger, "Why Not Birth Control Clinics in America?" Birth Control Review 3 (1919): 10-11; Linda Gordon, Woman's Body, 280-284. For more 
background on sterilization abuse and the racist history of the American birth control movement see Dorothy Roberts, Killing The Black Body, 209-219 and Linda Gordon, Woman's Body, Woman's Right, 282-313; Relf v. Weinberger, 372 F. Supp. 1196 (D.D.C. 1974)

Angela Davis, “The Historical Context:" 23.

Toni Cade Bambara, "The Pill: Genocide or Liberation," in The Black Woman: An Anthology, Toni Cade Bambara, ed. (New York: Washington Square Press, 2005): 162-169.

Michael Albert et al., Liberating Theory (Boston: South End Press, 1986), 6.

The Combahee River Collective, “The Combahee River Collective Statement.” In Feminism in Our Time, ed. Miriam Schneir,180.

Ross, "Raising Our Voices." In From Abortion to Reproductive Freedom, 140.

Silliman et al., Undivided Rights: Women of Color Organize for Reproductive Justice (Chicago, Illinois: Haymarket Books, 2016); National Black Women's Health Project, In From Abortion to Reproductive Freedom: 291; Lynn

Roberts, Loretta Ross, and M. Bahati Kuumba, "The Reproductive Health and Sexual Rights of Women of Color: Still Building a Movement," NWSA Journal 17, no. 1 (2005): 93-98.

Silliman et al., Undivided Rights, 42-50; Loretta Ross, interview (2001).

James C. Scott, Domination and the Arts of Resistance Hidden Transcripts, (New Haven, CT: Yale University Press, 2008): 198.

Jan Allen, Interview by Robin Payne (July 6, 2006), Interview U-0200, Southern Oral History

Program Collection (\#4007) in the Southern Historical Collection, Wilson Library, University of North Carolina at Chapel Hill.

xlvi Linda Villarosa, “Why America's Black Mothers and Babies are in a Life-or-Death Crisis," New York Times, 11 April 2018. 